\title{
Logistics Challenges Along the New Silk Roads
}

\author{
Hans-Dietrich Haasis $\mathbb{D}$, Jianhui Du $\mathbb{D}$, and Xuejun Sun
}

\begin{abstract}
In 2013, Chinese President Xi Jinping advised to establish the "Silk Road Economic Belt" and the "21st Century Maritime Silk Road," also referred as the Belt and Road Initiative or the New Silk Roads Policy. The intention is to promote international and regional trade as well as cooperation in and between Asia and Europe. Consequently, international maritime and terrestrial freight transport corridors are either established or strengthened and operated. The purpose of this paper is to reflect the Belt and Road Initiative from the perspective of logistics. The aim is to identify and formulate circumstances, expectations, opportunities, and peculiarities of logistics along the New Silk Roads. For this purpose, four corresponding challenges will be considered and outlined after an introduction to the Belt and Road Initiative. The four logistics challenges concern the awareness of new freight transport corridors and the assessment of possibilities for opening new transport relations and new markets, the implementation of new and the adaptation of existing supply chains to increase strategic logistics flexibility, the availability and use of digital infrastructure and connectivity for improved communication and coordination of logistical processes, and the willingness to consider regional and cultural differences in the preparation and realization of supply chain decisions.
\end{abstract}

\section{New Silk Roads Policy and Its Implications}

In 2013, China proposed to establish the "Silk Road Economic Belt" and the "21st Century Maritime Silk Road," also referred to the long-term development policy called Belt and Road Initiative, One Belt One Road, or New Silk Roads. Chinese President Xi Jinping first explains his vision of revitalizing the ancient Silk

H.-D. Haasis $(\bowtie)$

Faculty of Business Studies and Economics, University of Bremen, Bremen, Germany e-mail: haasis@uni-bremen.de

J. Du $\cdot$ X. Sun

Zhongyuan University of Technology, Zhengzhou, Henan, China

e-mail: jhd@zut.edu.cn; sunriver@126.com 
Road to jointly build the Silk Road Economic Belt at Nazarbayev University on September 7, 2013, as part of his state visit to Kazakhstan. One month later, on October 3, 2013, during his state visit to Indonesia he announced the 21st Century Maritime Silk Road. The Silk Road Economic Belt represents the land-based trade corridors linking Asia and Europe by establishing roads, railways, and pipelines. The 21st Century Maritime Silk Road indicates the maritime shipping passages spanning across the South China Sea, the South Pacific Ocean, and the Indian Ocean area. China's intention is to promote regional trade and cooperation through improving connectivity in Asia, Africa, and Europe. Chinese authorities encourage domestic enterprises to go global and actively cooperate with other states. Trade liberalization agreements are signed between China and countries influenced by the Belt and Road Initiative to promote trade and investment environments. Additional information is provided, for example, within (Lam et al. 2018; Lee et al. 2018; National Development and Reform Commission 2015; Wan 2021; Ye 2020; Ye and Haasis 2018).

In connection with infrastructure construction projects, large amounts of Chinese investments are already realized and will be realized in the future. Examples are, amongst others, the Port of Piraeus in Greece as well as the new Eurasian railway link connecting China, Central Asia and Europe. The Chinese National Development and Reform Commission, Ministry of Foreign Affairs and Ministry of Commerce, already in March 2015 released the first statement "Vision and Actions on Jointly Building Silk Road Economic Belt and 21st-Century Maritime Silk Road," which illustrates a grand blueprint as the strategic-level framework (National Development and Reform Commission 2015). The statement presents five major goals to enhance regional cooperation: policy coordination, facilities connectivity, unimpeded trade, financial integration, and people-to-people bonds. In the same year, Chinese government set up the Office of the Leading Group for Promoting the Belt and Road Initiative.

Although there are threats related to the cooperation arrangements like financial investment risks and political influence, the chances may outweigh according to the economic strengths and technological weaknesses of the countries and companies engaged in. At present, there are more than 50 countries signed cooperation agreements with China, according to the Chinese "Belt and Road Portal" (https:// eng.yidaiyilu.gov.cn/, last accessed 2021/06/25).

The pattern of logistics networks and supply chains is likely to be reshaped, and more countries and regions as well as their markets may become favorable for international enterprises and motivate facilities relocation processes (Hammami and Frein 2014; Khan and Haasis 2020; Rodrigue and Hesse 2006; Ye 2020; Ye and Haasis 2018). Against this background, logistics challenges may occur, for example, the revision of supply chain designs with respect to the availability of freight transport corridors, the ensuring of strategic logistics flexibility considering new logistics hubs and freight villages along the New Silk Roads, the accessibility to digital processes and communication platforms reducing digital divide conflicts, as well as the significance and appreciation of cultural influences on interregional supply chain decisions. 


\section{Freight Transport Corridors and Supply Chain Design}

Efficient as well as well-developed freight transport corridors are important, both for Europe and China as well as for the international networking of essential production sites with procurement and sales markets (Hammami and Frein 2014; Lee et al. 2018; Rodrigue and Hesse 2006). Their design and expansion aim

- to ensure economic accessibility for supply chains,

- to increase the attractiveness and visibility of the regions along the transport corridors,

- to increase the reliability, the cost-effectiveness, and the safety of freight transportation, as well as

- to ensure a future-oriented sustainable development of economic regions.

If this succeeds, transport corridors are valuable enablers for transport and trade facilitation, and thus for economic and social prosperity.

The demand for long-distance border-crossing freight transport is continuously growing in the economic globalization era, which puts a lot of pressure on the current global freight transportation system as well as on supply chains. Some transportation geographers also studied the transportation infrastructure and networks, container terminals, gateways, ports cooperation and regionalization, transportation network, etc., for example, see (Dovbischuk and Haasis 2011; Rodrigue 2012; Rodrigue and Hesse 2006).

Against this background, the terrestrial railway connections and the maritime transport relations to and from China play an essential role at the international level. This is mainly true in relation to the Chinese Belt and Road Initiative (Lam et al. 2018; Lee et al. 2018; National Development and Reform Commission 2015; Ye 2020; Ye and Haasis 2018). Figure 1 outlines the infrastructure network focusing

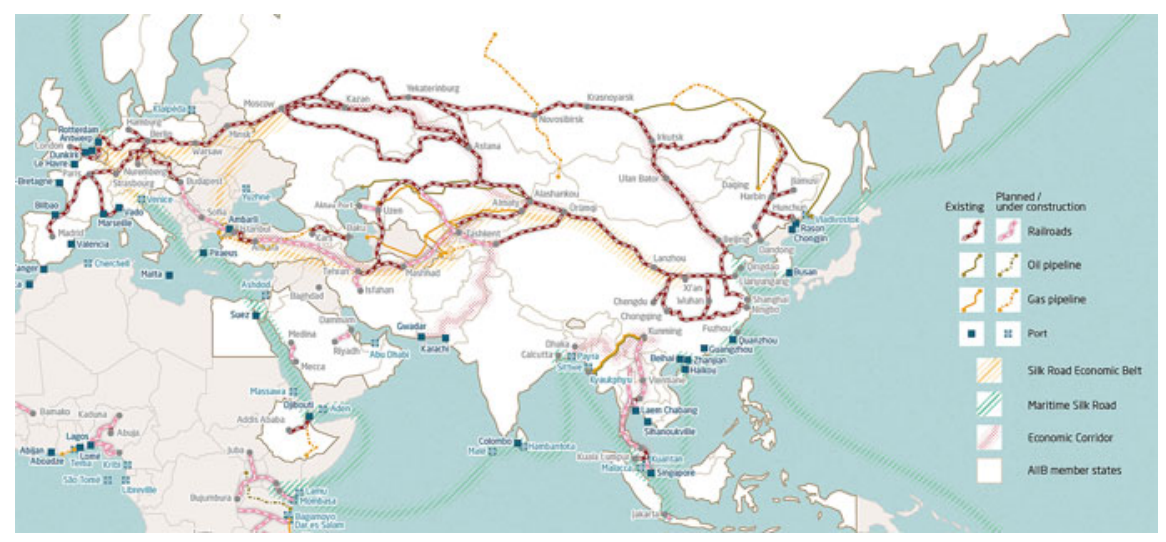

Fig. 1 Belt and Road Initiative-The infrastructure network (Source: Mercator Institute for China Studies, Berlin, 2018) 
on the Belt and Road Initiative. In addition, for Europe, the North-South axes as well as the West-East axes play an important role, i.e., the connection between Scandinavia and the Iberian Peninsula, the connection between the Baltic Sea and the Black Sea as well as the connection between Rotterdam, Duisburg, Warsaw, and Moscow. Focusing on Germany, the seaport hinterland connections are crucial for the performance of the German economy.

Congestion in important ports and insufficient capacity of distribution channels become bottlenecks for development and for the operation of supply chains. China's Belt and Road Initiative is an infrastructure-led development policy with large amounts of investments flowing into transportation infrastructure projects. These efforts are expected to expand the capacities of some critical ports and increase the connectivity of specific countries and regions to the global transportation system. Transportation infrastructure will affect firms' strategies about their network configuration and their supply chain design (Buer et al. 2019; Khan and Haasis 2020; Lee et al. 2018; Rodrigue and Hesse 2006; Ye 2020; Ye and Haasis 2018). The port of Piraeus as a case under the frame of the Belt and Road Initiative is a good example to illustrate how transportation infrastructure improvement affects the importance of this node in the entire network (Ye and Haasis 2018).

Of course, also the China Railway Express, operated by the state-owned enterprise China Railway Corporation, enables international container freight transport services between China and Europe. In the "Development Plan of China-Europe Freight Train Construction (2016-20)," issued by the Leading Group Office on the Construction of the Belt and Road (please see: https://eng.yidaiyilu.gov.cn/, last accessed 2021/06/25), the background and the demand for railway freight transport between China and European countries are analyzed. Moreover, the spatial structure design of the railway transit corridors, hub nodes, and routes is analyzed and published (Ye 2020).

There are three main railway passages: The western routes have three main branches; one runs through Kazakhstan connecting to the Trans-Siberian Railway; one crosses the border at Horgos Border port; one runs across Torugart pass and connects to the planned China-Kyrgyzstan-Uzbekistan Railway. The central route runs across Erlianhot land port and through Mongolia to connect to the TransSiberian Railway. The Eastern route goes across Manzhouli land port linking to Trans-Siberian Railway. All these passages end in European destinations.

Recently, enterprises are increasingly interested in relocating facilities; network redesign processes have become more frequent. Of course, enterprises are motivated by varying reasons such as offshoring, expansion opportunities to new markets, mergers and acquisitions, financial and tax advantages offered by countries (Hammami and Frein 2014).

In the context of the Belt and Road Initiative, the connectivity of selected locations is improved through investments in transportation infrastructure. Thus, national and regional governments should take advantage of these improvements and offer a more favorable business environment to attract enterprises' investments. On the other side, enterprises may reconsider their current network configuration and adapt their supply chain strategies to respond to the possible opportunities 
induced by the implementation of the Belt and Road Initiative (Ye 2020; Ye and Haasis 2018).

For the design and operation of these freight transport connections, it is important to consider the challenges of today and of the future, in particular the demands on freight mobility, the availability of energy resources, the efforts to protect the climate, the changes caused by the digital transformation of processes, and the need to integrate transport systems. Particularly from the point of view of climate and resources, rail transport and maritime transport play an important role (Tran et al. 2017). Finally, in view of the importance for the future freight transport system, investments in the provision and use of information and knowledge along the transport connections must also be considered (National Development and Reform Commission 2015; Wan 2021).

This shows that when dealing with supply chains along international or intercontinental freight transport routes, it is not only necessary to contribute to spatial planning and construction industry, but also to invest more than ever in the provision and use of information as well as to invest in the development and the assessment of innovative cooperation and business models.

\section{Logistics Hubs, Freight Villages, and Strategic Logistics Flexibility}

Considering the availability of new freight transport corridors, the strategic flexibility of an enterprise related to the operation of supply chains may increase. According to the supply chain design as well as the supply chain operation, these new options for freight transportation give the chance and supports to better respond to changes in the supply network access and the availability of logistics services along the longdistance transportation. The strategic logistics flexibility may be strengthened and improved. However, this depends on information and the presence and the scope of business activities in relation to logistics hubs and freight villages along the New Silk Roads.

Freight villages are specific logistics hubs. According to the DGG-Deutsche GVZ-Gesellschaft mbH (please see: gvz-org.de, last accessed 2021/06/25), they are defined as "logistics centers, where the cargo from different transport modes can be reloaded, compiled, and prepared for transportation. That place links and brings together different transport modes like road and rail, transport companies, supplementary transport services as well as industrial and trading companies. The spatial proximity promotes coopetition and division of labor of the enterprises on site. A major function of the freight villages is the management of politically promoted combined transport and the shifting of cargo traffic from road to rail. The cooperation of the companies on site makes it possible to realize high capacity utilization." 
More and more logistics hubs and freight villages like this can be found along the maritime shipping routes and, of course, along the three main railway passages between China and Europe, for example, the Horgos border port in Xinjiang, the Erlianhot land port and the Manzhouli land port.

As a transportation interface and a business area for logistics-focused services, freight villages are gaining wide acceptance in countries worldwide. Nowadays, the style on how to operate and collaborate in freight villages is often pointed out as a way for green logistics and sustainable freight transportation (Wu 2013; $\mathrm{Wu}$ and Haasis 2018). On the other hand, they provide added value services, such as inventory management, high-density warehousing, and packaging on behalf of manufacturing, retailing, and wholesaling customers. In addition, a freight village provides auxiliary facilities such as warehouses, groupage systems, customs, maintenance workshops, banks, insurance offices. Maybe in the future, they also provide decentralized additive manufacturing by using 3-dimensional printers (Barz et al. 2016), for example, in connection with customization of products for the customer.

Thus, freight villages are the foundation for intelligent and integrated freight transport and supply chain management on a regional, a national, and an international scale.

Logistics hubs and freight villages must be distinguished from so-called Special Economic Zones (Aggarwal 2011; Khan and Haasis 2020). To attract foreign direct investment these zones can be found within or nearby logistics hubs. However, the concept is focused on financial and tax policies. Whereas the aim of freight villages is to improve freight transportation and to motivate collaboration between coopetitive enterprises for a more efficient, green, and reliable supply chain.

On a regional scale, freight villages may be realized to organize regional and urban freight transport to and from sales markets or cities. On a national scale, freight villages support efficient, green, and reliable freight distribution between national supplier and sales markets using electricity-based rail transportation. And on an international scale, freight villages open the door to international transportation networks and markets. Thus, there are advantages for all stakeholders interested in transportation, for example, the customers, the workers, the regional authorities, the railway operators, the logistics service providers, the suppliers and the industrial companies by increasing their economic and social development and welfare.

Challenges linked to logistics hubs and freight villages are related to reliable connectivity, the organizational structure, the coopetitive business model, and the use of knowledge management for the improvement of collaboration. Investing in New Silk Roads also means to invest in capabilities, knowledge, and training.

Nowadays, the concept of logistics hubs and freight villages furthermore can be explained by the new economic geography theory, where spatial and agglomeration economies are the focal point. According to this theory, agglomeration is attributed to increasing returns of scales based on knowledge spillovers, market demand and cost of trade, as well as to infrastructure quality, the collaboration of enterprises and 
better technical and business environment (Aggarwal 2011; Dovbischuk and Haasis 2011).

\section{Digital Silk Roads, Platform Ecosystems, and Digital Divide}

Since several years the topic of digitalization has been discussed worldwide in connection with a better operation of processes as well as a shift of process control either or both, to the objects and the international web. This applies mainly to logistical processes (Freitag et al. 2020; Haasis et al. 2015; Jahn et al. 2020; Kersten et al. 2020; Wan 2021). In this context, digital transformation is the process of implementing digital technologies and supporting capabilities to create digital business models. However, due to high transaction costs in combination with a revision of business development and an implementation of change-management actions, the progress in digitalization goes on step by step and is obviously different between enterprises, regions, and states according to their related technological and human capabilities. The implementation of a digital silk road may support to overcome the dilemma of the digital divide.

Nevertheless, a rethinking of communication, coordination, and cooperation between stakeholders along a supply chain is obvious. Mainly concerning information management between partners in supply chains, there are substantial potentials for improving efficiencies. For example, efficiency improvements can be obtained by a better coordination along the international supply chain, by a more comprehensive and coopetitive regional cooperation, as well as by an innovative shifting of logistics control mechanisms into the cloud. By far, the options of modern information and communication technologies are not used sufficiently.

More and more decision-makers on a business level as well as on a political level focus on the design and operation of digital web-based service platforms based on the landlord philosophy. Public institutions may provide the digital infrastructure, and data transfer interfaces should be standardized across enterprises. The digital suprastructure could be developed and provided by private enterprises. Part of the digital suprastructure could be applications for the use of on-demand services, the use of logistics-oriented cyber-physical systems, the use of methods for data mining and data analyzing as well as the use of other coopetitive decision logics.

Thus, research and development towards collaborative decision-making, based on a coopetitive corporate policy, in ports, freight villages and in supply chains should be pushed by research institutions in close cooperation with enterprises. The same holds for the development of new data-driven control models for supply chain management and logistics operations, as well as for new business models (Haasis et al. 2015). In connection with business models, incentive schemes may be developed, overcoming the political motivated regional competition and realizing a coopetitive multi-plant cost calculation and a multi-plant profit allocation based on transfer 
payments. Of course, the incentive schemes must consider legal and operational requirements. Regarding new business models, the allocation of processes to process owners must be reconsidered. In the future, process owners of today may be substituted by process owners of tomorrow.

As known, in general, seaports are competitors, both from a business as well as from a regional political point of view. Of course, this is also true for terminal operators, logistics service providers and forwarders. Nevertheless, considering bottleneck situations, for example, stressed by port operations and by hinterland transportation as well as focusing on investments for port development and infrastructure provision, it may be an option to cooperate from time to time. This may lead to advantages like less waiting times in front of gates and terminals, better usage of straddle carriers and container yard capacities, as well as more time-efficient transshipment processes. Due to this, seaport communication and cooperation reflect typical situations for coopetition. The economic success of this coopetition may be enabled by an improved supply of digital information used for better communication and coordination between partners in the maritime supply chain as well as by a better allocation of scarce resources in line with collaborative decision-making. Examples for digital service innovations based on collaborative decision-making are yard and container lot management, ship announcement after re-direction and terminal preparation, gate drive-through management as well as a flexible and conditional supply chain management.

Maybe in the future a container ship decides autonomously about the best terminal and berth for container transshipment, or a vessel moored at a quay controls independently the terminal operations for its containers. Or a retailer will control the transshipment of requested containers towards the hinterland transportation to the demanding shop based on the specified demand of customer products. Or the container itself self-controls some of his operations on the container yard. These cloud-based applications in the future may be operated by using a digital web-based service platform across locations, upgraded on the base of port community systems and of terminal operating systems. The platform could have the characteristics of an essential facility. The related process model could be developed further towards a port-as-a-service-model. The port can be called a smart service port (Jahn et al. 2020).

Automation is already a real up-to-date development, for example, in selected terminals in the seaports of Hamburg, Busan, and Dubai. Considering the Next Generation Port 2030 in Singapore or the well-known TradeLens initiative of Maersk and IBM based on a blockchain-enabled digital shipping platform, the seaport 4.0 is approaching. Based on the philosophy of the well-known landlord model, as already mentioned, the digital platform could be provided as standardized public infrastructure, and the service applications could reflect the customerorientated private suprastructures. Algorithms and new data-driven applications for berth allocation, container yard operations, storage management and crane scheduling policies can be shifted towards cloud solutions. Of course, similar considerations can be made for freight villages and, in general, for logistics hubs. 
Thus, in the future the services could be offered by new Internet enterprises powered by data sources. The questions in the future are who will provide the digital business models on demand, who has the data power and on how to handle the digital divide between companies and regions. Therefore, related market consequences for seaports, freight villages and supply chains must be observed, analyzed, and challenged.

Finally, we must decide about the extent of external web-based control. This is a thrilling and challenging topic that should be covered in the context of discussions about the ethics of logistics.

The idea to achieve digital connectivity by integrating the concept of the internet of things and e-commerce into the Belt and Road Initiative was already mentioned in a White Paper prepared by the National Development and Reform Commission in 2015. In addition, the cross-border laying of optical cables and the expansion of communication networks were called for (National Development and Reform Commission 2015).

This policy of Digital Silk Roads was underlined by Lu Wei, the Director of the so-called Cyberspace Administration, in the China-EU Roundtable for Digital Cooperation in 2015. He mentioned: "We can build a digital silk road, a silk road in cyberspace" (Brown 2017).

\section{Interregional Supply Chain Decisions and Cultural Influences}

The implementation and the operation of supply chains along the New Silk Roads must deal with decision-makers and logistics service people with different cultural backgrounds. This is of course very clear in the widely recognized and accepted consideration of public holidays. However, these backgrounds may have an influence on the art on how to decide and on how to operate efficient and reliable logistics processes (Baumann et al. 2013; Fawcett et al. 2004; Ferraro and Briedy 2017; Hofstede et al. 2010; Smyrlis 2004). On the other hand, these backgrounds may result in the transfer of ideas, experiences, and knowledge between the regions and people along the New Silk Roads, as already happened in the past. Thus, besides only focusing on the supply chains of freight and goods, it is enhancing and worthwhile also to focus on the cultural chain of ideas and knowledge to increase the understanding and appreciation of decision-makers and people communicating, cooperating, and working together.

Maybe the focus on the people and their cultural differences, and by this on the cultural chain, could support the improvement of the logistics performance of companies and regions. Still, in some parts of Asia, contracts are just a general commitment to do business together and are less meaningful than personal relationships between individuals. Or what you believe to be a standard performance contract with a warehouse service provider containing a "circumstances change" clause, which 
essentially means the contract is not legally binding (Smyrlis 2004). According to the Logistics Performance Index, a benchmarking tool published by the World Bank (Arvis et al. 2018), there are still numerous challenges, but also opportunities, along the New Silk Roads, influencing the logistics performance, which must be handled by logistics people with different cultural backgrounds. The indicators considered for calculating the Logistics Performance Index are related to customs, infrastructure, service quality, timeliness, international shipping, and tracking and tracing. The characteristics of these indicators depend on people's decisions. By the way, the latest edition of the Logistics Performance Index allows for comparisons across 160 countries (Arvis et al. 2018): In 2018, Germany achieved rank 1, China was on rank 27, Kazakhstan on rank 71, and the Russian Federation on rank 75.

Obviously, the problems to ensure time-efficient and reliable processes are not only different languages, time zones, and measurement units, but behavior patterns and context interpretations. In connection with implementing logistics information systems and decision support tools, it is not uncommon, mainly in developing countries, to hear something like the following: "We were used to work without pressure and postponing some tasks for later because the system was not synchronized. Everyone was working for themselves without pressure. However, with this synchronized system, work must be always done instantaneously so that operations can take place on time. As a result, we feel that we are under pressure from the system and that we are no longer acting according to our own free will, but that we are subject to the system." This statement may underline those cultural aspects must be considered as part of interregional supply chain decisions to avoid misunderstanding and miscommunication. As well known, miscommunication increases uncertainty and risk and thus costs and can lead to wrong supply chain decisions.

This perspective clearly shows the importance of knowledge management within a region, a company, as well as between companies working together (Wu 2013). Human-centric knowledge management may help to identify cultural differences and to discuss these differences within an intercultural team providing new solutions for better cooperation and supply chain management. From this point of view, corresponding fresh reference should be given to topics like business process modeling, re-inventing of business models, business data analytics as well as the use of artificial intelligence for decision support and negotiation-orientated decision models (Baumann et al. 2013; Haasis et al. 2015).

\section{Synopsis and Conclusions}

Within this paper, logistics challenges are outlined related to the realization and operation of modified as well as new maritime and terrestrial silk roads based on the Belt and Road Initiative. Of course, besides the available infrastructure, people's decisions, services, business informatics, data analytics and innovation mainly influence the success of logistics both on a regional level as well as on 
an international level. Knowing that world trade flows are interconnected and changeable, logistics must nevertheless ensure distributed production and supply in a dynamic environment.

The aspects discussed are based on literature reviews as well as on studies accomplished at the Chair of Maritime Business and Logistics in Bremen in cooperation with researchers from China. The challenges mentioned within four chapters relate to the awareness of new freight transport corridors and the assessment of possibilities for opening new transport relations and new markets, the implementation of new and the adaptation of existing supply chains to increase strategic logistics flexibility, the availability and use of digital infrastructure and connectivity for improved communication and coordination of logistical processes, and the willingness to consider regional and cultural differences in the preparation and realization of supply chain decisions.

Of course, transport corridors are valuable enablers for transport and trade facilitation. However, decision-maker should be aware of the new corridors and should be able to evaluate both the supply chain risk as well as the economic and sustainable supply chain potential.

Strategic logistics flexibility may be increased by considering new logistics hubs and freight villages. However, this depends on information as well as on the presence and the scope of business activities in relation to logistics hubs and freight villages along the New Silk Roads. Thus, logistics hubs and freight villages are the foundation for intelligent and integrated freight transport as well as for supply chain management on a regional, a national, and an international scale.

The access to digital processes, innovations, and communication platforms is essential to increase the efficiency of logistics processes and supply chains. However, this access varies from company to company and from country to country. Moreover, the questions in the future are who will provide the digital business models and who has the data power. The implementation of a digital silk road may support to overcome at least the dilemma of the digital divide.

The operation of supply chains along the New Silk Roads takes into account decision-makers and logistics service people with different cultural backgrounds. Maybe a stronger focus on the people and their cultural differences, and by this on the cultural chain, could support the improvement of the logistics performance of companies and regions.

These remarks may motivate not only to invest in infrastructure, i.e., in ports, railway connections and warehouses, but also to invest in knowledge, research, education, training, communication, and understanding. By this, logistics actions along the New Silk Roads may serve as enabler and promoter for sustainable welfare as well as for a better international communication and peaceful cooperation from the point of view of states, regions, enterprises, and people.

Acknowledgments This paper is based on a project funded by the German Academic Exchange Service (DAAD) with financial resources from the Federal Ministry for Economic Cooperation and Development. 


\section{References}

Aggarwal, A.: Promoting agglomeration economies and industrial clustering through SEZs. J. Int. Econ. Commer. Policy. 2(2), 201-227 (2011)

Arvis, J.-F., Ojala, L., et al. (eds.): Connecting to Compete. Trade Logistics in the Global Economy. The World Bank, Washington (2018)

Barz, A., Buer, T., Haasis, H.-D.: Quantifying the effects of additive manufacturing on supply networks by means of a facility location-allocation model. Logistics Research 9(1), 13, pp. 1-14 (2016)

Baumann, T., Haasis, H.-D., Nehlsen-Pein, T.: Human decision making in business. Implications and application operations of neurosciences for business decisions. Bus. Syst. Rev. 2(1), 1-14 (2013)

Brown, R.: Beijing's Silk Road goes digital, www.cfr.org/blog/beijings-silk-road-goes-digital, last accessed 2021/06/25 (2017)

Buer, T., Haasis, H.-D., Kinra, A., Kotzab, H.: An overview to contemporary maritime logistics and supply chain management decision areas. In: Panayides, P.M. (ed.) The Routledge Handbook of Maritime Management, pp. 113-123. Routledge, London (2019)

Dovbischuk, I., Haasis, H.-D.: Path dependency in the process of sustainable regional development of transport and logistics regions. In: Ivanov, D., Kopfer, H., Haasis, H.-D., Schönberger, J. (eds.) Dynamics and Sustainability in International Logistics and Supply Chain Management, pp. 241-247. Cuvillier, Göttingen (2011)

Fawcett, S.E., Magnan, G.M., Williams, A.J.: Supply chain trust is within your grasp. Suppl. Chain Manag. Rev. 8(2), 20-26 (2004)

Ferraro, G.P., Briedy, E.K.: The cultural dimension of global business, 8th edn. Routledge, London (2017)

Freitag, M., Haasis, H.-D., Kotzab, H., Pannek, J. (eds.): Dynamics in Logistics. Springer, Cham (2020)

Haasis, H.-D., Landwehr, T., Kille, G., Obsadny, M.: Cloud-based eBusiness standardization in the maritime supply chain. In: Dethloff, J., Haasis, H.-D., Kopfer, H., Kotzab, H., Schönberger, J. (eds.) Logistics Management. Products, Actors, Technologies, pp. 256-276. Springer, Berlin (2015)

Hammami, R., Frein, Y.: Redesign of global supply chains with integration of transfer pricing: Mathematical modeling and managerial insights. Int. J. Prod. Econ. 158, 267-277 (2014)

Hofstede, G., Hofstede, G.J., Minkov, M.: Cultures and Organisations: Software of the Mind, 3rd edn. McGraw-Hill, New York (2010)

Jahn, C., Kersten, W., Ringle, C. M. (eds.) Data science in maritime and city logistics. epubli, Berlin (2020)

Kersten, W., Blecker, T., Ringle, C. M. (eds.) Digitalization in Supply Chain Management and Logistics. epubli, Berlin (2020)

Khan, A., Haasis, H.-D.: Spatially induced effects and sustainability for special economic zones: implications for zones in Pakistan under China Pakistan Economic Corridor. Region. Sci. Inquiry J. 2(12), 179-194 (2020)

Lam, J., Cullinane, K., Lee, S.-W.: The 21st-century Maritime Silk Road: Challenges and opportunities for transport management and practice. Transp. Rev. 38(4), 413-415 (2018)

Lee, G., Lee, S.-W., Feng, X.: Special Issue on 'Challenges and chances of the Belt and Road Initiative at the maritime policy and management level'. Marit. Policy Manag. 45(3), 279-281 (2018)

National Development and Reform Commission (ed.) Vision and actions on jointly building Silk Road Economic Belt and 21st Century Maritime Silk Road, http:// webcache.googleusercontent.com/search?q=cache:http://en.ndrc.gov.cn/newsrelease/201503/ t201503 30_669367.html, last accessed 2021/06/25 (2015)

Rodrigue, J.-P.: The geography of global supply chains: Evidence from third-party logistics. J. Supply Chain Manag. 48(3), 15-23 (2012) 
Rodrigue, J.-P., Hesse, M.: Global production networks and the role of logistics and transportation. Growth Chang. 37(4), 499-509 (2006)

Smyrlis, L.: Cultural differences can trump the most logical of supply chain planning. Canadian Transport. Logist. 107(9), 4-5 (2004)

Tran, N.K., Haasis, H.-D., Buer, T.: Container shipping route design incorporating the costs of shipping, inland/feeder transport, inventory and $\mathrm{CO}_{2}$ emissions. Marit. Econ. Logist. 19(4), 667-694 (2017)

Wan, Y: Improving the information flows and business process in global maritime logistics chains considering digitization and digitalization aspects. PhD thesis. University of Bremen, 2021

$\mathrm{Wu}$, J.: Sustainable freight village concepts for agricultural product logistics. A knowledge management-based study. PhD thesis. University of Bremen, 2013

$\mathrm{Wu}$, J., Haasis, H.-D.: The freight village as a pathway to sustainable agricultural products logistics in China. Journal of Cleaner Production, pp. 1227-1238 (2018)

Ye, J.: Regional orientated global logistics networks redesign with respect to the Belt and Road Initiative. $\mathrm{PhD}$ thesis. University of Bremen, 2020

Ye, J., Haasis, H.-D.: Investment of the Belt and Road Initiative. In: Freitag, M., Kotzab, H., Pannek, J. (eds.) Dynamics in Logistics, pp. 250-254. Springer, Heidelberg (2018)

Open Access This chapter is licensed under the terms of the Creative Commons Attribution 4.0 International License (http://creativecommons.org/licenses/by/4.0/), which permits use, sharing, adaptation, distribution and reproduction in any medium or format, as long as you give appropriate credit to the original author(s) and the source, provide a link to the Creative Commons licence and indicate if changes were made.

The images or other third party material in this chapter are included in the chapter's Creative Commons licence, unless indicated otherwise in a credit line to the material. If material is not included in the chapter's Creative Commons licence and your intended use is not permitted by statutory regulation or exceeds the permitted use, you will need to obtain permission directly from the copyright holder. 